\title{
Pediatric Asthma: Improving Management to Reduce Cost of Care
}

\author{
MICHAEL MELLON, MD, and BHASH PARASURAMAN, PhD
}

\begin{abstract}
BACKGROUND: The economic burden of pediatric asthma is substantial, with national annual health care costs of $\$ 3$ billion. Successful clinical management of asthma in children has the potential to decrease this burden by lowering the disproportionate costs of hospitalization and acute care for pediatric asthma patients.
\end{abstract}

RESULTS: Based on increased understanding of the pathogenesis of asthma, revised guidelines were published by the National Institutes of Health in 1997 (with an update in 2002) and by the American Academy of Allergy, Asthma, and Immunology in 1999 to assist in the diagnosis and management of pediatric asthma. These guidelines emphasize the role of inflammation in asthma and recommend treatment of the underlying inflammatory process. Despite increased knowledge regarding the pathogenesis of the disease and the availability of effective anti-inflammatory agents, particularly inhaled corticosteroids, the prevalence of asthma and disease-related morbidity continues to remain high in children.

CONCLUSION: Asthma interventions that include the use of guideline-recommended inhaled corticosteroid therapy and patient and caregiver education in asthma management may help to reduce asthma morbidity in children and decrease the substantial costs of pediatric asthma.

KEYWORDS: Asthma, Pediatric, Morbidity, Inhaled corticosteroids, Cost-effectiveness

J Manag Care Pharm. 2004;10(2):130-41
$\Lambda$ n estimated 6.3 million children in the United States had asthma in 2001. ${ }^{1}$ Despite the availability of effective controller medications, the annual rate of pediatric hospital admissions for asthma remains high. ${ }^{2-4}$ In an analysis of population-based data from California acute-care hospitals, asthma was ranked as the primary cause of hospitalization in children aged 1 to 5 years and the third cause of hospitalization in children aged 6 to 12 years. ${ }^{2}$ In 1999, the hospitalization rate was 55.4 admissions per 10,000 population among children aged 0 to 4 years and 21.5 admissions per 10,000 population among children aged 5 to 14 years (Figure 1). ${ }^{5}$ The emergency department visit rates also were high for these age groups.

The disproportionate share of costs for hospitalization and unscheduled emergency care of children with asthma is largely responsible for the significant economic burden of pediatric asthma. ${ }^{6}$ The national annual health care cost for pediatric asthma is approaching $\$ 3$ billion, of which direct treatment costs account for approximately $\$ 2$ billion and indirect costs $\$ 1$ billion. ${ }^{7}$ An analysis of the per capita impact of pediatric asthma on health care utilization and total costs, based on 1987 National Medical Expenditure Survey data, demonstrated that children with asthma had more inpatient hospital days $(0.23$ versus 0.11 per year), required $65 \%$ more nonurgent outpatient

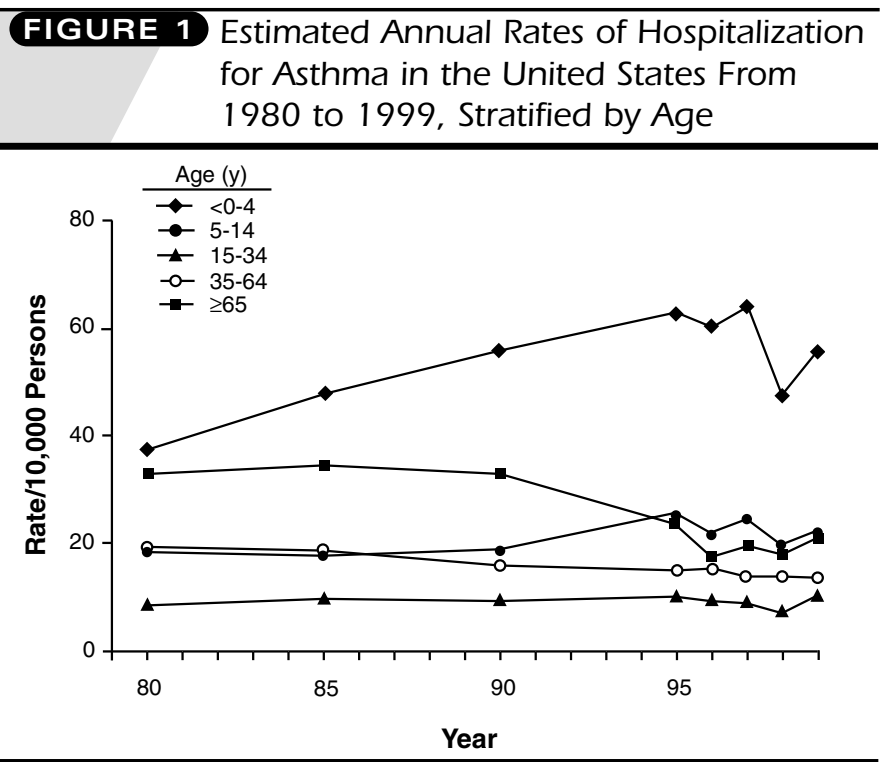

Source: Mannino DM, Homa DM, Akinbami LJ, et al. Surveillance for asthmaUnited States, 1980-1999. MMWR Surveill Summ. 2002;51:1-13.
MICHAEL MELLON, MD, is a pediatric allergist, Department of Allergy, Kaiser Permanente Medical Center, San Diego, CA, and an associate clinical professor of pediatrics, University of California-San Diego School of Medicine, La Jolla, and BHASH PARASURAMAN, PhD, is a director and team leader, Health Economics and Outcomes Research, AstraZeneca LP, Wilmington, Delaware.

AUTHOR CORRESPONDENCE AND REPRINT REQUESTS: Michael Mellon, MD, Kaiser Permanente Medical Offices, Allergy Dept., 5th Fl., 7060 Clairemont Mesa Blvd., San Diego, CA 92111. Tel: (858) 573-0299; Fax: (858) 573-5612; E-mail: michael.h.mellon@kp.org

Copyright $\odot$ 2004, Academy of Managed Care Pharmacy. All rights reserved. 

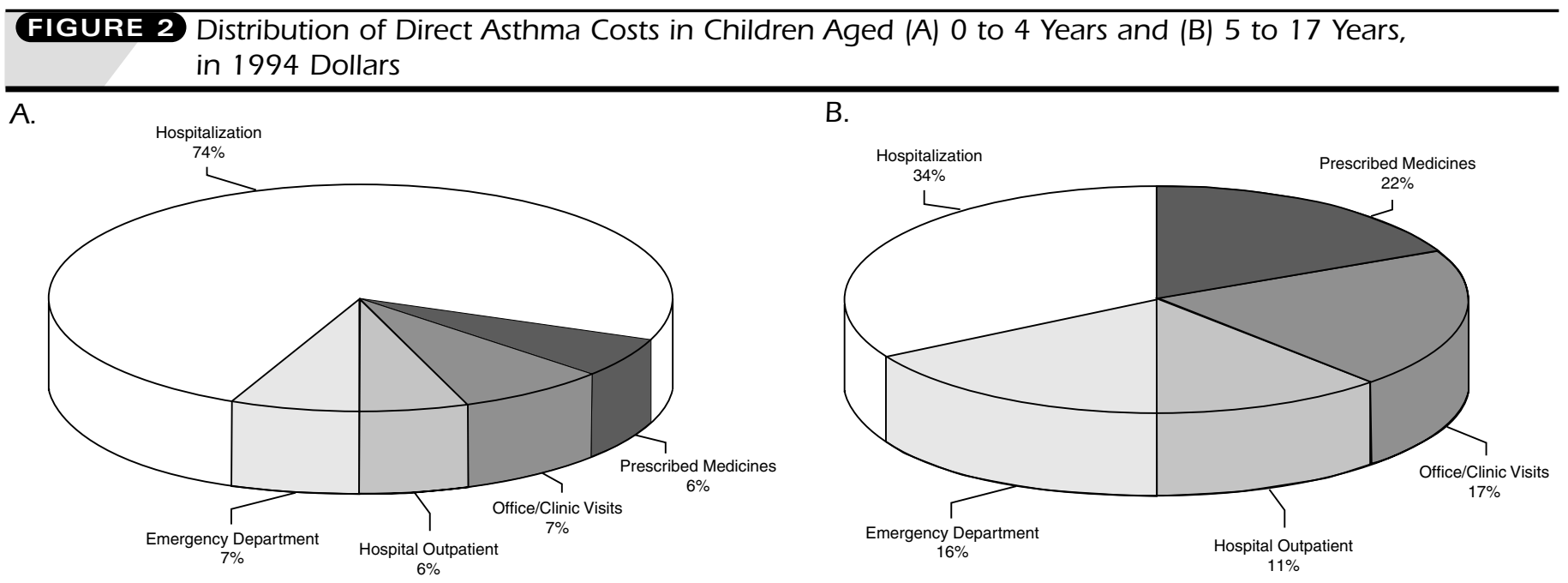

Source: Smith DH, Malone DC, Lawson KA, et al. A national estimate of the economic costs of asthma. Am J Respir Crit Care Med. 1997;156:787-93. ${ }^{9}$

clinic visits, filled 2.8 times more prescriptions, and incurred $88 \%$ higher medical expenses than those without asthma. ${ }^{8}$ Analysis of the 1987 data inflated to 1994 dollars showed that hospitalizations accounted for the greatest proportion of direct costs in children aged 0 to 4 years (\$586.2 million) and 5 to 17 years ( $\$ 286.2$ million) (Figure 2).9 A more recent analysis of cost estimates for 1994 showed similarly high costs for hospitalization of children younger than 18 years ( $\$ 514.3$ million). ${ }^{10}$ Emergency department visits comprised approximately $7 \%$ to $19 \%$ of total direct costs for patients younger than 18 years, ${ }^{4,9,10}$ with costs estimated at $\$ 228.7$ million in $1994 .^{10}$

Pediatric asthma results in 14 million missed school days each year. ${ }^{1}$ Considerable indirect costs are therefore incurred as a result of workdays lost by caregivers of children with asthma. ${ }^{4}$ In 1994, children aged 5 to 17 years missed 11.8 million school days. ${ }^{10}$ These missed days cost an estimated $\$ 956.7$ million for caretakers' time lost from work and housekeeping. ${ }^{11}$ For 1998, these costs were projected at $\$ 1.1$ billion. ${ }^{11}$

Missed school days and increased hospitalizations and emergency care for children with asthma suggest poor disease management. Although hospital length of stay and emergency department visits decreased from 1985 to 1994, the costs for these services increased over the same time period..$^{10}$ The use of hospital services contributes to higher costs for asthma management than does appropriate physician and pharmaceutical care. ${ }^{6.9}$ Guidelines for health care management in patients with asthma have been developed, $, 2,13$ and adherence to these standards decreases hospitalization costs. ${ }^{14}$ The guidelines outline steps for early recognition of children with asthma and appropriate intervention with pharmacologic agents and health education.

\section{Improving Care to Reduce Costs}

Because hospitalizations account for a large proportion of direct costs of pediatric asthma ( $74 \%$ and $34 \%$ of direct costs in children aged 0 to 4 years and 5 to 17 years, respectively), ${ }^{9}$ measures aimed at improving care to reduce hospital use would significantly decrease the overall costs of pediatric asthma. These strategies include accurate diagnosis and assessment of disease severity, appropriate pharmacologic intervention and follow-up, and programs designed to teach patients and their parents to monitor and manage asthma. Furthermore, patients must be taught to understand and accept the importance of adhering to prescribed therapy and avoiding possible precipitating factors to minimize acute episodes.

A randomized controlled study reported by Greineder et al. demonstrated a $75 \%$ reduction in hospitalizations $(P<0.05)$ among children aged 1 to 15 years with asthma who participated in a comprehensive asthma outreach program. ${ }^{15}$ The program was focused on ensuring that patients kept scheduled pediatric appointments, monitored their asthma, and took maintenance medications. Reduced hospitalizations, along with significant reductions in emergency department use (57\%, $P<0.05)$ and out-of-health-plan use including referrals, home care, and durable medical equipment $(71 \%, P<0.001)$, contributed to an estimated direct savings of $\$ 7.69$ to $\$ 11.67$ for every dollar spent on the intervention.

\section{Diagnosis of Asthma in Infants and Children}

Difficulty in diagnosing asthma in children leads to frequent underdiagnosis, resulting in many cases of undertreatment. ${ }^{12}$ The diagnosis is particularly difficult because the 2 most com- 
FIGURE 3 NAEPP: Stepwise Approach for Managing Asthma in Infants and Young Children (Aged $\leq 5$ Years)

\begin{tabular}{|c|c|c|c|}
\hline & \multirow[b]{3}{*}{$\begin{array}{c}\text { Step } 2 \\
\text { Mild Persistent }\end{array}$} & \multirow[b]{2}{*}{$\begin{array}{c}\text { Step } 3 \\
\text { Moderate Persistent }\end{array}$} & $\begin{array}{c}\text { Step } 4 \\
\text { Severe Persistent }\end{array}$ \\
\hline & & & $\begin{array}{l}\text { Symptoms: } \\
\text { Daytime: continual } \\
\text { Nighttime: frequent }\end{array}$ \\
\hline & & $\begin{array}{l}\text { Symptoms: } \\
\text { Daytime: daily }\end{array}$ & Preferred treatment: \\
\hline & Symptoms: & & \\
\hline $\begin{array}{c}\text { Step 1 } \\
\text { Mild Intermittent }\end{array}$ & $\begin{array}{c}\text { Daytime: }>2 \mathrm{x} / \text { week } \\
\text { but }<1 \mathrm{x} / \text { day } \\
\text { Nighttime: }>2 \text { nights/month }\end{array}$ & $\begin{array}{l}\text { Preferred treatments: } \\
\text { - Low-dose ICS + LABA" } \\
\text { - Medium-dose ICS }\end{array}$ & $\begin{array}{l}\text { If needed: } \\
\text { High-dose ICS + LABA + } \\
\text { corticosteroid tablets }\end{array}$ \\
\hline $\begin{array}{l}\text { Symptoms: } \\
\text { Daytime: } \leq 2 \text { days/week } \\
\text { Nighttime: } \leq 2 \text { nights/month }\end{array}$ & $\begin{array}{l}\text { Preferred treatment: } \\
\text { - Low-dose ICS* (with } \\
\text { nebulizer, } \mathrm{MDI}^{\dagger} \text { with holding }\end{array}$ & $\begin{array}{l}\text { Alternative treatments: } \\
\text { - Low-dose ICS + either } \\
\text { LTRA or theophylline }\end{array}$ & $\begin{array}{l}\text { (2 mg/kg/day, generally } \\
\text { do not exceed } 60 \mathrm{mg} / \text { day })\end{array}$ \\
\hline $\begin{array}{c}\text { No daily } \\
\text { medication needed }\end{array}$ & $\begin{array}{l}\text { chamber with or without } \\
\text { face mask, or DPI) } \\
\text { Alternative treatment: } \\
\text { - Cromolyn (nebulizer is } \\
\text { preferred or MDI with } \\
\text { holding chamber) } \\
\text { - LTRA } \$\end{array}$ & $\begin{array}{l}\text { If needed: } \\
\text { Preferred: medium-dose } \\
\text { ICS + LABA } \\
\text { - Alternative: medium-dose } \\
\text { ICS + either LTRA or } \\
\text { theophylline }\end{array}$ & \\
\hline $\begin{array}{l}\text { Quick Relief (all sever } \\
\text { - Bronchodilator as needed } \\
\text { spacer/holding chamber ar } \\
\text { - With viral respiratory infecti } \\
\text { consider systemic corticost } \\
\text { - Use of short-acting } \beta_{2} \text {-ago } \\
\text { controller therapy, and dail }\end{array}$ & $\begin{array}{l}\text { ies of asthma) } \\
\text { preferred, with oral } \beta_{2} \text {-agonists } \\
\text { n use a bronchodilator every } 4 \text { t } \\
\text { roids for severe exacerbations } \\
\text { ists }>2 \text { times/week for intermitte } \\
\text { or increasing use in persistent }\end{array}$ & $\begin{array}{l}\text { ad } \beta_{2} \text {-agonists by nebulizer or } \\
\text { as an alternative. } \\
6 \text { hours up to } 24 \text { hours (no mo } \\
\text { r a patient history of severe ex } \\
\text { th asthma may indicate the ne } \\
\text { sthma may indicate the need } t\end{array}$ & $\begin{array}{l}\text { ace mask and } \\
\text { e than once every } 6 \text { weeks); } \\
\text { acerbations. } \\
\text { d to initiate long-term } \\
\text { increase control therapy. }\end{array}$ \\
\hline * ICS $=$ inhaled corticoster & $\S L T R$ & $=$ leukotriene receptor ant & agonist. \\
\hline $\begin{array}{l}\dagger \mathrm{MDI}=\text { metered-dose inh } \\
\ddagger \mathrm{DPI}=\text { dry-powder inhale }\end{array}$ & $/ / L A B$ & $=$ long-acting $\boldsymbol{\beta}_{2}$-agonist . & \\
\hline $\begin{array}{l}\text { Source: National Asthma } \\
\text { nosis and management of } \\
110 \text { (suppl 5):S141-S219. }\end{array}$ & $\begin{array}{l}\text { ucation and Prevention Pro } \\
\text { hma. Update on selected }\end{array}$ & $\begin{array}{l}\text { gram. Expert panel repor } \\
\text { pics-2002. J Allergy Cli }\end{array}$ & $\begin{array}{l}\text { Guidelines for the diag- } \\
\text { Immunol. 2002; }\end{array}$ \\
\hline
\end{tabular}

treatment options and provide optimal disease management. Disease severity is based on symptoms in preschool children (Figure 3) and on symptoms and pulmonary function in older children who are capable of performing pulmonary function tests (Figure 4). According to a national survey that included parents of 721 children with asthma, based upon symptoms, $54 \%$ of children were classified with mild intermittent asthma, 21\% with mild persistent asthma, 14\% with moderate persistent asthma, and 12\% with severe persistent disease. ${ }^{20}$

\section{Pharmacotherapy}

Asthma is well established as a chronic inflammatory disease that results from a complex interaction among inflammatory, airway epithelial, and endothelial cells. ${ }^{21}$ Persistent asthma is most effectively controlled by daily anti-inflammatory therapy. Although leukotriene modifiers and other long-term control medications are available, corticosteroids are considered the most potent and consistently effective anti-inflammatory medications available. ${ }^{12,13}$ Recent long-term studies have established a robust safety profile for inhaled corticosteroids (ICSs). ${ }^{22}$ They have long been an important and often life-saving therapy for patients with severe asthma. However, the long-term use of systemically administered corticosteroids in mon symptoms of asthma in children-cough and wheeze-are encountered in many other childhood illnesses. ${ }^{16}$ Among children aged 5 years or younger, diagnosis is complicated by the challenge in obtaining objective measurements of lung function. ${ }^{12}$ Although spirometry generally is recommended for diagnostic purposes in adults, children cannot reliably perform these tests due to the mechanics involved..$^{12,17}$ Thus, in younger children, the diagnosis must be based on symptoms, history, and physical examination. ${ }^{12,17}$

Not all children who wheeze during infancy will develop persistent asthma, thus it is important to be able to distinguish these infants with transient wheeze from those with early-onset asthma. Data suggest that wheeze will subside by the age of 6 years in at least $60 \%$ of children who wheeze with viral infections in early life. ${ }^{18}$ A predictive index for persistent asthma in children (Table 1) has been developed to help determine which young children with wheeze will go on to develop persistent disease. ${ }^{19}$

Asthma severity must be accurately assessed to evaluate pression, skin and bone changes, and growth impairment. ${ }^{23}$

ICSs were developed to maximize local anti-inflammatory effects in the lungs and to minimize unwanted systemic effects. The potential for ICSs to produce clinically significant systemic adverse effects is limited. In general, ICS doses of $400 \mathrm{mg} /$ day or less in children do not appear to affect adrenal function. ${ }^{24}$ Short-term growth velocity may be affected initially by ICSs, but clinical studies evaluating long-term growth in children suggest that final adult height is not adversely affected. ${ }^{22,25}$

A randomized controlled trial of 1,041 children aged 5 through 12 years with mild-to-moderate persistent asthma found that 4 to 6 years of treatment with inhaled budesonide was superior in many clinical outcomes to either nedocromil or placebo but caused a small, transient reduction in growth velocity that was apparent mostly within the first year of treatment. ${ }^{22}$ At treatment end, bone age and projected final height in children treated with budesonide and nedocromil were similar to children is associated with adverse effects such as adrenal sup- 
placebo. A paper published coincidentally by Agertoft and Pedersen involving 211 children who had achieved final adult height included 142 children treated with budesonide (mean daily dose, $412 \mu \mathrm{g}$ ) for a mean of 9.2 years. In this paper, the authors concluded that long-term treatment with budesonide is not associated with reduction in normal height in adulthood. ${ }^{25}$ To minimize the potential for unwanted systemic effects, it is important to monitor growth in children receiving ICS therapy and to step down to the minimum effective dose. ${ }^{12}$

The National Institutes of Health guidelines for the prevention and management of asthma provide specific recommendations for safe and effective use of ICSs in children. ${ }^{12,13}$ Asthma treatment recommendations for children aged 5 years or younger (Figure 3) differ slightly from those for adults and children aged 5 years or older (Figure 4). ICSs are recommended as the preferred treatment for infants and children of any age with mild persistent asthma, and they are recommended along with long-acting $\beta_{2}$-agonists for all patients with moderate or severe persistent asthma and as an additional preferred treatment (at a medium dose) for children aged 5 years or younger with moderate persistent disease. ${ }^{13}$ In patients with intermittent asthma, as-needed use of short-acting $\beta_{2}$-agonists (SABAs) is recommended.

Differences in physiochemical and pharmacokinetic properties exist among corticosteroids. However, all of the currently available agents have demonstrated efficacy in the treatment of asthma in various age groups of children. ${ }^{23}$ Use of these agents has been associated with improved pulmonary function, decreased symptoms, and reduced airway hyperresponsiveness. ${ }^{23}$

Several ICS products are available for the management of childhood asthma. In the United States, the pressurized metered-dose inhaler (pMDI) formulations of triamcinolone acetonide, beclomethasone dipropionate, and flunisolide and the dry-powder inhaler formulation of budesonide are approved by the U.S. Food and Drug Administration and available for use in children older than 6 years. ${ }^{26}$ One dry-powder inhaler formulation of fluticasone is approved and available for use in children as young as 4 years.
Budesonide inhalation suspension (Pulmicort Respules), a nebulized corticosteroid formulation, is the only ICS product approved for children younger than 4 years and available for children as young as 1 year.

\section{Medication Delivery Needs in Pediatric Asthma}

Optimal delivery of asthma medications to infants and children can be challenging. Inhaled therapy is preferred over systemic therapy to reduce the potential for systemic effects and to deliver higher drug concentrations directly to the airways. ${ }^{7}$ However, poor inhaler technique is $\operatorname{common}^{27,28}$ and often leads to the failure of inhaled medication in children. ${ }^{29}$

Common errors demonstrated by children include failure to coordinate actuation and inhalation, and inhalation through the nose after actuation into the mouth. ${ }^{27,28}$ To ensure optimal delivery of inhaled medication, delivery devices should meet the 


\section{TABLE 1 Predictive Indices for Asthma in Children*}

\begin{tabular}{ll}
\hline Major Criteria & Minor Criteria \\
- Parent with a history of & $\bullet$ Physician diagnosis of \\
physician-diagnosed asthma & allergic rhinitis \\
- Physician diagnosis of eczema & $\bullet$ Wheezing apart from colds \\
& $\bullet \geq 4 \%$ eosinophilia
\end{tabular}

\footnotetext{
* Loose index for the prediction of asthma: early wheezer plus $\geq 1$ major criterion or 2 minor criteria. Stringent index for the predication of asthma: early frequent wheezer plus $\geq 1$ major criterion or 2 minor criteria.
}

Adapted with permission from Castro-Rodriguez JA, Holberg CJ, Wright AL, Martinez FD. A clinical index to define risk of asthma in young children with recurrent wheezing. Am J Respir Crit Care Med. 2000;162:1403-06. ${ }^{19}$

\section{TABLE 2 Inhalation Devices and Recommended Patient Ages}

\begin{tabular}{ll}
\hline Device & Age $^{*}$ \\
\hline pMDI $\dagger$ & $>5$ years $(<5$ years with \\
& spacer/holding chamber \\
& $\begin{array}{l}\text { and face mask for some } \\
\text { children })\end{array}$
\end{tabular}

Breath-actuated $>5$ years pMDI

Comments

Child may have difficulty
coordinating inhalation. Use with a spacer/holding chamber helps.

Child may not be able to generate necessary inspiratory flow. Device does not require the use of holding chamber or spacer

Dry-powder inhaler $>5$ years (can be used in Some devices deliver drug 4 years olds, but delivery more effectively than a is more consistent in those $>5$ years)

Nebulizer Patients of any age who cannot use a pMDI with spacer/holding chamber or face mask.
pMDI. Some devices may not work in children with low inspiratory volumes.

Useful in infants and very young children and any child with a moderate-tosevere asthma episode. Delivery method of choice for cromolyn sodium.

\footnotetext{
* These ages are suggested as guides for making clinical decisions. The physician should tailor treatment to the specific needs and circumstances of the child and family.

$\dagger$ pMDI $=$ pressurized metered-dose inhaler .

Adapted with permission from the American Academy of Allergy, Asthma $E$ Immunology. Pediatric Asthma: Promoting Best Practice. Guide for Managing Asthma in Children. Milwaukee, WI: American Academy of Allergy, Asthma E Immunology, Inc.; 1999. (C2002, all rights reserved.) ${ }^{7}$
}

specific needs of the child, ${ }^{7}$ and instruction should be given in the proper use of these devices. ${ }^{28}$ Failure to effectively use inhaler devices may directly increase treatment costs. ${ }^{30}$

Some young children who have difficulty coordinating the actuation and inhalation of pMDIs can effectively use these devices with spacers, holding chambers, or face masks, whereas others may require a nebulizer to properly administer inhaled

therapy (Table 2). ${ }^{7}$ Delivery difficulties observed with the use of pMDIs in infants and young children may result in suboptimal or inappropriate treatment

A phase-out of chlorofluorocarbon (CFC)-propelled pMDIs, for environmental reasons, and transition to hydrofluoroalkane (HFA)-propelled inhalers is currently taking place. Reformulation of HFA-pMDI medications may affect patient acceptability, and costs of reformulating may be prohibitive for compounds that are not used to a great extent. HFAbeclomethasone (QVAR) is approved for use in children aged 5 years or older. HFA-beclomethasone has been shown to be cost effective compared with the CFC formulation.

In a 12-month, multicenter, randomized, open-label, parallelgroup study, Price et al. showed that patients aged 12 years or older with stable asthma had a significantly higher percentage of symptom-free days with HFA-beclomethasone compared with about half the dose of CFC-beclomethasone (42.4\% versus 20.0\%) and clinically significant improvement in health-related quality of life with the HFA formulation. ${ }^{31}$ Based on the incremental cost per symptom-free day, HFA-beclomethasone appeared to be cost effective compared with CFC-beclomethasone.

Nebulization is a preferred method for delivering inhaled medications to infants and young children who cannot use other delivery devices. ${ }^{7}$ Until recently, cromolyn sodium nebulizer solution was the only nebulized anti-inflammatory medication approved for the long-term control of asthma in U.S. children.

Budesonide inhalation suspension, the only ICS available in the United States in a nebulized formulation, was shown to be more effective than nebulized cromolyn sodium in children aged 2 to 6 years with mild-to-moderate persistent asthma, based on patient outcomes ${ }^{32}$ and caregiver quality of life. ${ }^{33}$ After 52 weeks, children receiving budesonide (mean daily dose, 0.54 to $0.61 \mathrm{mg}$ ) demonstrated a significantly lower asthma exacerbation rate compared with cromolyn (mean daily dose, 65.0 to $76.3 \mathrm{mg})(1.23 \pm 1.99$ versus $2.41 \pm 6.13$ exacerbations/year) and significantly longer times to first exacerbation $(216.63 \pm 146.20$ versus $147.78 \pm 140.77$ days $)$ and use of additional long-term asthma medication $(320.52 \pm 99.59$ versus $235.09 \pm 140.31)(P<0.001$ for all). Caregivers of children treated with budesonide showed significantly less limitation in daily activities and emotional functioning compared with caregivers of cromolyn-treated children $\left(P<0.001\right.$ for both). ${ }^{33}$

Nebulized budesonide has been used worldwide for the treatment of persistent asthma. In the United States, its safety and efficacy have been assessed in 3 randomized, double-blind, placebo-controlled trials involving a total of 1,017 children..$^{34-36}$

In children aged 6 months to 8 years with mild persistent asthma, budesonide $0.25,0.5$, and $1.0 \mathrm{mg}$ once daily significantly decreased nighttime and daytime asthma symptoms compared with placebo $(P \leq 0.05)$ and reduced use of $\beta_{2}$-agonist rescue medication $(P \leq 0.038) .{ }^{34}$ Similarly, in children aged 
6 months to 8 years with moderate persistent asthma, once- or twice-daily budesonide therapy improved nighttime and daytime asthma symptom scores and decreased use of rescue medication compared with placebo. ${ }^{35}$

Improvements in asthma symptoms were significantly greater compared with placebo in children receiving budesonide inhalation suspension 0.25 and $0.5 \mathrm{mg}$ twice daily and $1.0 \mathrm{mg}$ once daily $(P \leq 0.05)$. Improvement was not statistically significant compared with placebo in the $0.25-\mathrm{mg}$ once-daily budesonide treatment group. Compared with placebo, patients in all budesonide treatment groups showed a significantly reduced need for $\beta_{2}$-agonist use from baseline to treatment end $(P \leq 0.014)$.

In children aged 4 to 8 years with corticosteroid-dependent asthma, budesonide inhalation suspension $0.25 \mathrm{mg}, 0.50 \mathrm{mg}$, or $1.0 \mathrm{mg}$ twice daily significantly reduced the use of breakthrough medications $(P \leq 0.032)$ and improved nighttime and daytime symptom scores $(P \leq 0.026)$ compared with placebo. ${ }^{36}$ There were no differences in the frequency, severity, or types of adverse events reported in the budesonide inhalation suspension groups compared with the placebo groups in these 3 trials.

\section{Early Pharmacologic Intervention}

The National Asthma Education and Prevention Program Working Group on the Financing of Asthma Care highlights the importance of early intervention for successful asthma management. ${ }^{9}$ In a study of children and adults aged 15 to 64 years with newly diagnosed asthma, early use of ICSs resulted in greater improvements in objective and subjective variables compared with SABA therapy. ${ }^{37}$ Notably, improvement in morning peak expiratory flow was $32.8 \mathrm{~L} / \mathrm{min}$ for budesonide compared with $4.8 \mathrm{~L} / \mathrm{min}$ for terbutaline $(P<0.001)$. Budesonide also significantly reduced bronchial hyperresponsiveness $(P<0.001)$, asthma symptoms $(P<0.01)$, and use of supplemental $\beta_{2}$-agonist therapy $(P<0.01)$.

In a continuation of this study, patients who received budesonide therapy at study onset had improved lung function compared with patients who received terbutaline for 2 years before initiating ICSs. ${ }^{38}$ The authors noted that maintenance therapy usually could be given at a reduced dose. Another study demonstrated that the mean budesonide dose necessary to maintain long-term disease control in children with mild-to-moderate asthma decreased significantly over the course of the study, suggesting that treatment costs also may decrease over time. ${ }^{39}$

Studies also found that a longer duration of symptoms before treatment was associated with smaller improvements in lung function in both children ${ }^{39}$ and adults ${ }^{40}$ with mild-to-moderate persistent asthma. Furthermore, treatment with ICSs at least partially reversed basement membrane thickness in adult patients with mild asthma. ${ }^{41}$ These findings suggest that early treatment with ICSs may prevent development of chronic airway obstruction.

\section{Underuse of Inhaled Corticosteroids}

Despite guideline recommendations for ICSs as daily first-line therapy in pediatric asthma, underuse of ICSs is widespread.2-46 A recent cross-sectional survey of children aged 5 to 17 years enrolled in 2 managed care plans revealed that only 55\% of those with moderate and severe persistent asthma used longterm control medication daily. ${ }^{47}$

A second study in a managed care setting demonstrated that less controller medication was dispensed for children aged 3 to 5 years compared with older children ${ }^{48}$ Furthermore, Yamada et al. reported inadequate medication regimens in a study of 87 children aged 3 to 12 years who were treated for acute asthma in the year before study enrollment. ${ }^{44}$ These studies demonstrate a need for more accurate assessment of disease severity and more frequent use of ICSs consistent with that assessment.

\section{Use of Inhaled Corticosteroids} Reduces Health Resource Utilization

Underuse of ICSs may contribute to hospitalization and the need for repeated emergency care. ${ }^{49}$ Wennergren et al. showed a gradual decrease over 15 years in the number of hospital days per year and number of admissions for children aged 2 to 18 years that coincided with a continuous increase in the number of children with asthma being treated with ICSs over the same time period. ${ }^{50}$ Other studies demonstrated that ICSs could reduce the risks of hospitalization and emergency department visits in children aged 3 to 15 years $^{51}$ and the risk of hospitalization in adults and children, ${ }^{52}$ compared with no controller therapy. Agertoft and Pedersen similarly demonstrated a significant reduction in the number of annual hospitalizations in children with mild-to-moderate persistent asthma treated with inhaled budesonide ( 0.0041 hospitalizations per child) compared with theophylline, $\boldsymbol{\beta}_{2}$-agonists, and cromolyn sodium (0.030 hospitalizations per child) $(P<0.001){ }^{39}$

The Childhood Asthma Management Program study demonstrated a $43 \%$ lower rate of hospitalization in children treated with budesonide (2.5 hospitalizations per 100 person-years) compared with placebo (4.4 hospitalizations per 100 person-years), whereas there was no significant difference for those treated with nedocromil (4.3 hospitalizations per 100 person-years). In this study, the adjusted annual rates for urgent care visits because of asthma in the budesonide and nedocromil groups were significantly lower ( $45 \%$ and $27 \%$, respectively) than those for the placebo group. ${ }^{22}$ Finally, in the study by Leflein et al. involving children aged 2 to 6 years with mild-to-moderate persistent asthma, nebulized budesonide inhalation suspension was significantly more effective than cromolyn sodium nebulizer solution. Patients receiving budesonide demonstrated significantly fewer yearly urgent care visits (0.15 versus 0.30$)$, unscheduled physician visits for asthma (2.2 versus 2.8), unscheduled telephone calls to physician offices (4.8 versus 6.3), and days of oral corticosteroid use (6.3 versus 9.3) $(P<0.01$ for all $) .32$ 
Pediatric Asthma: Improving Management to Reduce Cost of Care

TABLE 3 Clinical Studies Reporting Health Care Utilization and Costs With Inhaled Corticosteroid Treatment

\begin{tabular}{llllll}
\hline Study & $\begin{array}{l}\text { Study } \\
\text { Design }\end{array}$ & Length & $\begin{array}{l}\text { Enrolled } \\
\text { Patients }\end{array}$ & Treatments & Outcomes \\
\hline $\begin{array}{l}\text { Murphy } \\
(2003)^{33} \text { and }\end{array}$ & $\mathrm{R}^{*}, \mathrm{OL}^{\dagger}$, & 52 weeks & 426 & Budesonide 0.5 mg/day & \% of patients with \\
Leflein & $\mathrm{PG}^{\ddagger}$ & & & vs. cromolyn $80 \mathrm{mg} /$ day & hospitalization: \\
$(2002)^{32}$ & & & & $\begin{array}{l}\text { for } 8 \text { weeks, with dosage } \\
\text { adjustments thereafter }\end{array}$ & ED $^{\S}$ visit:
\end{tabular}

Urgent care visit:

Similar between groups adjustments thereafter

$8 \%$ for budesonide vs. $12 \%$ for cromolyn

Caregiver quality of life: Greater improvements in

$11 \%$ for budesonide vs. $21 \%$

for cromolyn activity limitations, emotional function, and total quality-of life scores for budesonide

\begin{tabular}{|c|c|c|c|c|c|}
\hline \multirow[t]{2}{*}{$\begin{array}{l}\text { Andersson } \\
(2001)^{53}\end{array}$} & \multirow[t]{2}{*}{$\mathrm{R}, \mathrm{OL}, \mathrm{PG}$} & \multirow[t]{2}{*}{12 months } & \multirow[t]{2}{*}{138} & $\begin{array}{l}\text { Budesonide } 400 \mu g / \text { day- } \\
800 \mu \mathrm{g} / \text { day vs. cromolyn }\end{array}$ & SFDs": \\
\hline & & & & $60 \mathrm{mg} /$ day & Yearly cos \\
\hline $\begin{array}{l}\text { Bisgaard } \\
(2001)^{54}\end{array}$ & $\mathrm{R}, \mathrm{DB},{ }^{\mathrm{q}} \mathrm{PG}$ & 12 weeks & 237 & $\begin{array}{l}\text { Fluticasone } 100 \mu \mathrm{g} / \text { day } \\
\text { and } 200 \mu \mathrm{g} / \text { day vs. placebo }\end{array}$ & $\mathrm{GP}^{\#}$ visit: \\
\hline
\end{tabular}

$14 \%$ increase with switch to budesonide

$24 \%$ lower for budesonide 21 for fluticasone $100 \mu \mathrm{g} / \mathrm{day}$ and 15 for $200 \mu \mathrm{g} / \mathrm{day}$ vs. 30 for placebo

\begin{tabular}{|c|c|c|c|c|}
\hline $\begin{array}{l}\text { CAMP }^{* *} \\
(2000)^{22}\end{array}$ & R, DB, PG & $4-6$ years & 1,041 & $\begin{array}{l}\text { Budesonide } 400 \mu \mathrm{g} / \text { day } \\
\text { and nedocromil } 16 \mathrm{mg} / \text { day } \\
\text { vs. placebo }\end{array}$ \\
\hline
\end{tabular}

\begin{tabular}{lllll} 
& & & $\begin{array}{l}\text { Rate of urgent care } \\
\text { visits: } \\
\text { Nighttime awakenings: }\end{array}$ \\
\hline $\begin{array}{l}\text { Booth } \\
(1996)^{55}\end{array}$ & R, OL, PG 8 weeks 305 & $\begin{array}{l}\text { Fluticasone } 100 \mu \mathrm{g} / \text { day } \\
\text { vs. cromolyn } 80 \mathrm{mg} / \text { day }\end{array}$ & $\begin{array}{l}\text { Lack of symptoms in last } \\
3 \text { weeks of study: } \\
\text { daytime: }\end{array}$
\end{tabular}

\begin{tabular}{|c|c|c|c|c|c|c|}
\hline & & & & & Nighttime: & $\begin{array}{l}80 \% \text { of patients for fluticasone } \\
\text { vs. } 65 \% \text { for cromolyn }\end{array}$ \\
\hline & & & & & Cost-effectiveness: & $\begin{array}{l}\text { Fluticasone was more than twice } \\
\text { as cost effective as cromolyn }\end{array}$ \\
\hline $\begin{array}{l}\text { Agertoft and } \\
\text { Pedersen } \\
(1994)^{39}\end{array}$ & $\begin{array}{l}\text { Controlled, } \\
\text { prospective }\end{array}$ & $3-7$ years & 278 & $\begin{array}{l}\text { Budesonide } 800 \mu \mathrm{g} / \mathrm{day} \\
\text { for } 6-8 \text { weeks, with dosage } \\
\text { adjustments thereafter; } \\
\text { control patients continued } \\
\text { regular non-ICS treatment }\end{array}$ & Hospitalizations: & $\begin{array}{l}.0041 / \text { patient/year for } \\
\text { budesonide vs. 03/patient/year } \\
\text { for controls }\end{array}$ \\
\hline $\begin{array}{l}\text { Connett } \\
(1993)^{56}\end{array}$ & $\mathrm{R}, \mathrm{DB}, \mathrm{PG}$ & 6 months & 40 & $\begin{array}{l}\text { Budesonide } 400 \mu \mathrm{g} / \text { day } \\
800 \mu \mathrm{g} / \text { day vs. placebo }\end{array}$ & SFDs: & $\begin{array}{l}\text { Mean } 62 \text { for budesonide vs. } \\
38 \text { for placebo }\end{array}$ \\
\hline & & & & & Cost/SFD: & $\begin{array}{l}\mathcal{£} 7.17 \text { (U.S. } \$ 13.07 \text { ) for } \\
\text { budesonide vs. } £ 16.16 \text { (U.S. } \$ 29.48 \text { ) } \\
\text { for placebo }\end{array}$ \\
\hline & & & & & Cost-effectiveness ratio: & $\begin{array}{l}£ 6.33 \text { (U.S. - } \$ 11.55 \text { ) in favor } \\
\text { of budesonide }\end{array}$ \\
\hline & & & & & Missed work days: & $\begin{array}{l}\text { Mean } 1.9 \pm 4.9 \text { for budesonide } \\
\text { vs. } 2.6 \pm 6.0 \text { for placebo }\end{array}$ \\
\hline $\begin{array}{l}\text { Rutten- } \\
\text { van Mölken }\end{array}$ & $\mathrm{R}, \mathrm{DB}, \mathrm{PG}$ & 3 years & 116 & $\begin{array}{l}\text { Budesonide } 1,200 \mu \mathrm{g} / \text { day } \\
\text { vs. placebo, plus SABA }\end{array}$ & SFDs: & $\begin{array}{l}\text { 212/patient-year for budesonide } \\
\text { vs. } 174 / \text { patient-year for placebo }\end{array}$ \\
\hline$(1993)^{57}$ & & & & & Yearly cost: & $\begin{array}{l}\text { 43\% reduction with addition of } \\
\text { budesonide }\end{array}$ \\
\hline & & & & & Missed school days: & $\begin{array}{l}\text { Mean } 1.7 \text { day/year for budesonide } \\
\text { vs. } 3.7 \text { day/year for placebo }\end{array}$ \\
\hline $\begin{array}{l}* R=\text { random } \\
\dagger O L=\text { open } l \\
\ddagger P G=\text { parall }\end{array}$ & & $\begin{array}{ll}\S & E D \\
\text { // } & S F L \\
\text { I } & D B\end{array}$ & symp & $\begin{array}{l}\# G P=\text { gene } \\
* \text { * CAMP }= \\
+\$ S A B A=s h\end{array}$ & $\begin{array}{l}\text { practitioner. } \\
\text { ldhood Asthma Managen } \\
\text { t-acting } \beta_{2} \text {-agonist. }\end{array}$ & Program. \\
\hline
\end{tabular}

Direct cost:

Hospitalization rate:

$\$ 1.73$ and $\$ 1.80 /$ patient/day vs. $\$ 2.60 /$ patient/day for placebo

$43 \%$ lower for budesonide; not significantly different for nedocromil

$45 \%$ lower for budesonide; $27 \%$ lower for nedocromil Similar between groups

$71 \%$ of patients for fluticasone vs. $55 \%$ for cromolyn $80 \%$ of patients for fluticasone vs. $65 \%$ for cromolyn as cost effective as cromolyn budesonide vs. 03/patient/year for controls 38 for placebo (U.S. $\$ 29.48$ of budesonide Mean $1.9 \pm 4.9$ for budesonide 212/patient-year for budesonide vs. 174/patient-year for placebo $\sim 43 \%$ reduction with addition of Mean 1.7 day/year for budesonide vs. 3.7 day/year for placebo 


\section{Economic Value of Inhaled Corticosteroids}

The cost-effectiveness of ICS therapy in children has been demonstrated in numerous clinical studies (Table 3). A study from the United Kingdom examined the relative cost-effectiveness of budesonide therapy compared with placebo in 40 children aged 1 to 3 years with symptoms of persistent asthma despite $\boldsymbol{\beta}_{2}$-agonist therapy. ${ }^{56}$ The study found that budesonide significantly increased the number of symptom-free days compared with placebo (62 versus 38 days/patient, respectively), while lowering the estimated total annual cost of asthma care (£1397.83 versus $£ 1891.43$ per patient/year). Although drug costs were higher for children treated with budesonide than for those given placebo ( $£ 188.73$ versus $£ 47.53$ per patient/year, respectively), the additional expense was more than offset by reductions in costs for physician consultations, hospitalizations, and days lost from work or playgroup.

In a Dutch study, Rutten-van Mölken et al. compared the cost-effectiveness of SABA therapy plus an ICS with SABA therapy plus placebo in 116 children aged 7 to 16 years. ${ }^{57}$ Although the addition of an ICS to $\beta_{2}$-agonist treatment resulted in an increase in treatment cost compared with placebo, the overall impact was a decrease in all other direct health care costs (e.g., antibiotic treatment, outpatient therapy, and hospitalization). When decreases in the indirect costs resulting from parents' lost productivity because of asthma-related school absenteeism were considered in the cost-effectiveness analysis, overall savings were further increased.

The outcomes and cost benefits of introducing ICS therapy to a U.S. Medicaid population were reported in a 2-year claimsbased study involving 413 patients, 39\% of whom were younger than 16 years. ${ }^{58}$ Patients were monitored for 1 year before and 1 year after the initiation of ICS therapy in the case group. Hospitalizations decreased by $50 \%$ and outpatient visits decreased by $26 \%$ after initiation of ICSs, but hospitalizations increased $23 \%$ and outpatient visits increased by $36 \%$ in the control group. After adjusting for confounding variables, patients receiving ICS therapy had monthly health care cost savings of almost $24 \%$.

Health care costs associated with ICS therapy also were assessed in a retrospective, matched-cohort, U.S. study involving ICS ( $\mathrm{n}=99,57 \%$ younger than 13 years) and noncorticosteroid groups ( $\mathrm{n}=297,55 \%$ younger than 13 years). ${ }^{59}$ Patients received any combination of asthma medications except ICSs during the first 6 months of the study period. ICS therapy was then initiated in 1 group and continued throughout the 18 -month study. Monthly payments for prescriptions increased from $\$ 59$ to $\$ 116$ in the ICS group and from $\$ 53$ to $\$ 55$ in the noncorticosteroid group. However, the average monthly payments for medical care decreased to $\$ 28$ in the ICS group because of reduced clinic visits, emergency department visits, and hospitalizations, and these costs increased to $\$ 89$ in the noncorticosteroid group. Thus, the increased cost of ICS therapy was offset by the decreased costs of medical care for this population of patients. The authors concluded that ICS therapy improved health care outcomes without increasing the overall cost of care.

Few studies have directly compared the cost-effectiveness of different controller medications in children, and well-controlled cost-effectiveness trials comparing ICS products for the pediatric population have not been conducted. ${ }^{60}$ Indeed, such comparisons can be difficult as the type of delivery device used by the child can affect cost. For example, a European study demonstrated that aggregated medication costs were lower for ICSs delivered via pMDI with Nebuchamber than with either Babyhaler or Aerochamber because of more efficient drug delivery. ${ }^{61}$ A significantly lower mean dose of inhaled budesonide also was required when delivered via Turbuhaler compared with Nebuhaler in children with asthma, ${ }^{39}$ and the lower doses could translate into cost savings. Nevertheless, a recent Swedish study comparing the costs of budesonide and sodium cromoglycate therapy in children aged 5 to 11 years found that budesonide therapy was associated with $24 \%$ lower annual costs. ${ }^{53}$

\section{Economic Value of Health Education}

A lack of self-management skills by children with asthma or their caregivers contributes to overuse of hospital emergency departments by these children. ${ }^{62}$ Asthma education programs aim to prevent or minimize acute asthma episodes by enhancing self-management behavior, increasing medication compliance, and improving patient-provider communication. Studies have shown these programs to be effective in decreasing asthma morbidity and associated health care costs for both adults and children. ${ }^{63-67}$

In a randomized trial of 310 children from low-income families, Clark et al. evaluated the ability of health education to improve asthma self-management. ${ }^{63}$ Topics discussed in the program included managing an asthma attack, taking medicine, communicating with the physician, and maintaining a healthy home environment. Among children who had been hospitalized in the previous year, those who subsequently received health education had a significantly greater decrease in emergency department visits $(-3.84 \pm 8.46$ versus $0.06 \pm 14.24, P=0.04)$ and hospitalizations $(-1.00 \pm 0.33$ versus $-0.31 \pm 1.35, P=0.03)$ compared with those in the control group. For enrolled patients, the program saved $\$ 11.22$ in emergency department and hospitalization costs for every $\$ 1$ spent to deliver health education.

A recent study by Kelly et al. also evaluated the effectiveness of a comprehensive asthma education and outreach program in decreasing emergency department utilization and hospitalization among Medicaid-insured pediatric patients with mild, moderate, or severe persistent asthma ${ }^{64}$ The intervention was based on National Heart, Lung, and Blood Institute (NHLBI) guidelines and was similar in content to the program of Clark et al. Among children in the intervention group, the number of emergency department visits decreased from 3.6 visits per child 
in the year before the intervention to 1.7 visits per child $(P<0.05)$. Hospitalizations decreased from 0.6 to $0.2(P<0.001)$, and days in the hospital per child decreased from 2.4 to $0.9(P<0.001)$. The average asthma health care charges decreased by $\$ 721$ (24\%) per child per year in the intervention group, despite the additional cost of subspecialty care in the clinic and salary support for the outreach nurse. Although the cost of outpatient medications was not included in the overall cost analysis, the authors estimated that the savings from decreased hospitalization rates would outweigh the costs related to daily ICS therapy.

An integral component of this outreach program involved liaison between the patient and provider through monthly contacts with an asthma outreach nurse. The relationship between patients, their families, and their care providers is an important component of health education interventions. ${ }^{12}$

\section{Economic Value of Pharmacy-based Intervention}

There is great potential for expansion of the pharmacist's role in a multidisciplinary approach to asthma management. Pharmacists can play a greater role in providing information to patients about asthma medications, the importance of medication adherence, and proper medication delivery for optimal disease management. Pharmacists can also contribute to safer and more effective disease management by monitoring medication use and refill intervals and alerting physicians when antiinflammatory medications are suspected of being underused or quick-relief medications overused. ${ }^{68}$

A transition from purely dispensing medications to working directly with physicians and patients may have a favorable impact on patient disease outcomes and health care utilization..$^{69}$ Numerous studies have demonstrated a positive effect of pharmacist intervention on outcomes in adult patients with chronic diseases, including asthma. ${ }^{70-74}$ In a 1-year pharmacybased intervention study carried out in community pharmacies throughout Denmark, ${ }^{75}$ pharmacists counseled patients (aged 16 to 60 years) with asthma and reviewed patient inhaler technique on a monthly basis. Pharmacists also recorded asthma symptoms and lung function and monitored patient diaries.

Compared with patients not receiving intervention, patients in the intervention group demonstrated greater knowledge of asthma and asthma medications $(P<0.001)$, with fewer errors in inhaler technique $(P<0.001)$ and greater improvement in asthma symptom status $(P=0.004)$ and asthma-specific quality of life $(P<0.001)$. During the last 6 months of the study, 3.81 days of sickness were experienced per patient in the intervention group compared with 6.57 days per patient in the control group $(P=0.078)$. Additionally, there were only 4 hospitalizations and 17 asthma clinic visits in the intervention group compared with 11 hospitalizations and 30 clinic visits in the control group. ${ }^{75}$

A similar study conducted in younger asthma patients, aged 6 to 17 years, ${ }^{76}$ demonstrated no significant effect of pharmacy intervention on health or health care utilization. Differences in lung function improvement, asthma severity, and quality of life were not significantly different based on intervention. Furthermore, there were no differences in the rates of asthmaspecific hospitalizations, emergency department visits, or physician visits between patients in the intervention and control groups. The authors noted that the intervention might not have been powerful enough to have a significant effect on pharmacist behavior and patient outcomes and that compliance with the study protocol was low among pharmacists because of patientand practice-based obstacles.

Pharmacists reported that obstacles to intervention were most frequently patient-based. For example, scheduling interventions was difficult in this young population because of school attendance, and patients lacked motivation to participate, perhaps because they "interpreted their meetings with pharmacists as unwelcome reminders of a medical condition that sets them apart from their peers."

\section{Economic Value of Public Health}

Numerous public health issues have an impact on asthma burden and subsequent health care costs. It is clear that minority patients and those who are impoverished and living in the inner city suffer higher morbidity and mortality due to asthma. ${ }^{77,78}$ Lack of a primary care provider may contribute significantly to the high asthma morbidity and resource utilization in children from low-income families, who may be more likely to use the emergency department as a source of primary care.

Higgins et al. evaluated the influence of family and provider intervention on asthma costs in 61 pediatric patients with asthma (mean age, 8.4 years) who were treated frequently in the emergency department (mean, 1.36 times per year, with 1.78 mean annual admissions). ${ }^{65}$ These children were assigned to a primary care provider. Both parents and primary care providers received education regarding the NHLBI Guidelines for the Diagnosis and Management of Asthma.

Based on a retrospective review of the medical records, resources used by the patient for a mean of 58.1 months before intervention were compared with resource utilization per patient during the 11.2 months after intervention. Assessments demonstrated that intervention led to decreased health resource utilization and costs (Table 3). Annual cost savings in 1997 dollars after intervention were estimated at $\$ 4,845$ per patient. This study shows the value of incorporating patient and provider educational programs into the clinical management of pediatric asthma to reduce morbidity and overall disease costs.

Because health resource use is disproportionately high among disadvantaged populations, treatment interventions might provide greater improvement in asthma outcomes and reduce the need for emergency intervention in these patients. ${ }^{6}$ Multifaceted, inner-city interventions that include patient education and counseling, treatment, and environmental control measures have demonstrated improved asthma control in inner city children, with reduced hospital admissions ${ }^{64,78,79}$ and asthmarelated costs. ${ }^{64}$ 
Exposure to outdoor pollutants has a significant impact on asthma control. ${ }^{80,81}$ The proportion of pediatric asthma costs in the United States attributable to environmental pollutants (i.e., toxic chemicals in the air, water, food, or community) has been estimated at $30 \% .{ }^{82}$ Greater relative risk of respiratoryrelated hospitalizations associated with air pollution in uninsured patients or patients on Medicaid compared with privately insured patients suggests an effect of socioeconomic or health care disparities on this environmental factor. ${ }^{83}$

\section{Conclusion}

From 1985 to 1994, the estimated total cost of illness for pediatric (younger than 17 years) asthma increased from $\$ 2.25$ billion (in 1994 dollars) to $\$ 3.17$ billion despite a $15.5 \%$ decrease in the cost of care per child. ${ }^{10}$ This decrease in per-child costs was primarily driven by shorter lengths of hospital stay for children. National trends during this same period show only a $2.8 \%$ decrease in the number of hospitalizations (pediatric and adult) for asthma compared with a $15.5 \%$ decrease for all causes of hospitalization. Thus, there is a continued need to improve asthma management to reduce the economic burden of pediatric asthma.

It is the responsibility of all health care providers who care for children with asthma to advance the agenda of appropriate education and environmental control. Furthermore, all children should have proper severity classification and, if persistent asthma is diagnosed, should be on a controller agent. Pharmacists are in a unique position to monitor for SABA overuse and to ensure that children with asthma and their caregivers understand the importance of daily use of controller medications, their mechanisms of action, and the proper delivery technique needed for optimal benefit.

\section{ACKNOWLEDGMENTS}

Leslie Sell, PhD, director, Medical Communications, Scientific Connexions, Newtown, PA, provided assistance in drafting the manuscript. Marissa Buttaro, MPH, director, Medical Communications, Scientific Connexions, Newtown, PA, provided assistance in revising and editing the manuscript.

\section{DISCLOSURES}

Funding for this review was provided by AstraZeneca LP and was obtained by author Bhash Parasuraman, who is employed by AstraZeneca LP. Author Michael Mellon is a consultant to AstraZeneca LP and participates in a speakers bureau for clients including AstraZeneca LP, GlaxoSmithKline, and Merck. Mellon served as principal author of the study. Study concept and design, analysis and interpretation of data, and drafting of the manuscript and its critical revision were the work of both authors. Administrative, technical, and/or material support was provided by Scientific Connexions, Newtown, Pennsylvania.

\section{REFERENCES}

1. American Lung Association. Epidemiology \& Statistics Unit, Research and Scientific Affairs. Trends in Asthma Morbidity and Mortality. March 2003. New York, NY: American Lung Association; 2003.

2. Chabra A, Chávez GF, Taylor D. Hospital use by pediatric patients: implications for change. Am J Prev Med. 1997;13(suppl 2):30-37.
3. Perrin JM, Homer CJ, Berwick DM, et al. Variations in rates of hospitalization of children in three urban communities. N Engl J Med. 1989;320:1183-87.

4. Weiss KB, Gergen PJ, Hodgson TA. An economic evaluation of asthma in the United States. N Engl J Med. 1992;326:862-66.

5. Mannino DM, Homa DM, Akinbami LJ, et al. Surveillance for asthmaUnited States, 1980-1999. MMWR Surveill Summ. 2002;51:1-13.

6. Sullivan S, Elixhauser A, Buist AS, et al. National Asthma Education and Prevention Program Working Group report on the cost effectiveness of asthma care. Am J Respir Crit Care Med. 1996;154(3, pt 2):S84-S95.

7. American Academy of Allergy, Asthma \& Immunology. Pediatric Asthma: Promoting Best Practice. Guide for Managing Asthma in Children. Milwaukee, WI: American Academy of Allergy, Asthma \& Immunology, Inc.; 1999.

8. Lozano P, Fishman P, VonKorff M, Hecht J. Health care utilization and cost among children with asthma who were enrolled in a health maintenance organization. Pediatrics. 1997;99:757-64.

9. Smith DH, Malone DC, Lawson KA, et al. A national estimate of the economic costs of asthma. Am J Respir Crit Care Med. 1997;156:787-93.

10. Weiss KB, Sullivan SD, Lyttle CS. Trends in the cost of illness for asthma in the United States, 1985-1994. J Allergy Clin Immunol. 2000;106:493-99.

11. Weiss KB, Sullivan SD. The health economics of asthma and rhinitis. I. Assessing the economic impact. J Allergy Clin Immunol. 2001;107:3-8.

12. U.S. Dept. of Health and Human Services. National Asthma Education and Prevention Program. Guidelines for the Diagnosis and Management of Asthma: Expert Panel Report 2/National Institutes of Health, National Heart, Lung, and Blood Institute. Bethesda, MD: U.S. Dept. of Health and Human Services, Public Health Service, National Institutes of Health, National Heart, Lung, and Blood Institute; 1997. NIH publication 97-4051.

13. National Asthma Education and Prevention Program. Expert panel report: guidelines for the diagnosis and management of asthma. Update on selected topics-2002. J Allergy Clin Immunol. 2002; 110(suppl 5):S141-S219.

14. Nestor A, Calhoun AC, Dickson M, Kalik CA. Cross-sectional analysis of the relationship between national guideline recommended asthma drug therapy and emergency/hospital use within a managed care population. Ann Allergy Asthma Immunol. 1998;81:327-30.

15. Greineder DK, Loane KC, Parks P. A randomized controlled trial of a pediatric asthma outreach program. J Allergy Clin Immunol. 1999;103:436440 .

16. Lemanske RF Jr, Busse WW. Asthma. JAMA. 1997;278:1855-73.

17. Foucard T. Aggressive treatment of childhood asthma with local steroids. Good or bad? Allergy. 1996;51:367-71.

18. Martinez FD. Present and future treatment of asthma in infants and young children. J Allergy Clin Immunol. 1999;104(4, pt 2):S169-S174.

19. Castro-Rodríguez JA, Holberg CJ, Wright AL, Martinez FD. A clinical index to define risk of asthma in young children with recurrent wheezing Am J Respir Crit Care Med. 2000;162:1403-06.

20. Asthma in America. A landmark survey [executive summary]. Asthma in America; Washington, DC: December 1998.

21. Djukanovic R, Roche WR, Wilson JW, et al. Mucosal inflammation in asthma. Am Rev Respir Dis. 1990;142:434-57.

22. The Childhood Asthma Management Program Research Group. Long-term effects of budesonide or nedocromil in children with asthma. N Engl J Med. 2000;343:1054-63.

23. Pedersen S, O'Byrne P. A comparison of the efficacy and safety of inhaled corticosteroids in asthma. Allergy. 1997;52(suppl 39):1-34.

24. Kamada AK, Szefler SJ, Martin RJ, et al. Issues in the use of inhaled glucocorticoids. Am J Respir Crit Care Med. 1996;153:1739-48.

25. Agertoft L, Pedersen S. Effect of long-term treatment with inhaled budesonide on adult height in children with asthma. N Engl J Med. 2000;343:1064-69.

26. Nebulized budesonide for asthma in children. Med Lett Drugs Ther. 2001;43:6-7. 
27. Pedersen S, Østergaard PA. Nasal inhalation as a cause of inefficient pulmonal aerosol inhalation technique in children. Allergy. 1983;38:191-94.

28. Pedersen S, Frost L, Arnfred T. Errors in inhalation technique and efficiency in inhaler use in asthmatic children. Allergy. 1986;41:118-24.

29. Clough J. Asthma in the very young. Practitioner. 1995;239:198-202.

30. King D, Earnshaw SM, Delaney JC. Pressurised aerosol inhalers: the cost of misuse. Br J Clin Pract. 1991;45:48-49.

31. Price D, Haughney J, Duerden M, Nicholls C, Moseley C. The cost-effectiveness of chlorofluorocarbon-free beclomethasone dipropionate in the treatment of chronic asthma. A cost model based on a 1-year pragmatic, randomized clinical study. Pharmacoeconomics. 2002;20:653-64

32. Leflein JG, Szefler SJ, Murphy KR, et al. Nebulized budesonide inhalation suspension compared with cromolyn nebulizer solution for asthma in young children: results of a randomized outcomes trial. Pediatrics. 2002;109:866-72

33. Murphy KR, Fitzpatrick S, Cruz-Rivera M, Miller CJ, Parasuraman B. Effects of budesonide inhalation suspension compared with cromolyn sodium nebulizer solution on health status and caregiver quality of life in childhood asthma. Pediatrics. 2003;112(3, pt 1):e212-19. Available at http://www.pediatrics.org.

34. Kemp JP, Skoner DP, Szefler SJ, et al. Once-daily budesonide inhalation suspension for the treatment of persistent asthma in infants and young children. Ann Allergy Asthma Immunol. 1999;83:231-39.

35. Baker JW, Mellon M, Wald J, et al. A multiple-dosing, placebo-controlled study of budesonide inhalation suspension given once or twice daily for treatment of persistent asthma in young children and infants. Pediatrics. 1999;103 414-21.

36. Shapiro G, Mendelson L, Kraemer MJ, et al. Efficacy and safety of budesonide inhalation suspension (Pulmicort Respules) in young children with inhaled steroid-dependent, persistent asthma. J Allergy Clin Immunol. 1998; 102:789-96

37. Haahtela $T$, Järvinen $M$, Kava $T$, et al. Comparison of a $\boldsymbol{\beta}_{2 \text {-agonist, terbu- }}$ taline, with an inhaled corticosteroid, budesonide, in newly detected asthma. N Engl J Med. 1991;325:388-92.

38. Haahtela T, Järvinen M, Kava T, et al. Effects of reducing or discontinuing inhaled budesonide in patients with mild asthma. N Engl J Med. 1994;331: $700-05$.

39. Agertoft L, Pedersen S. Effects of long-term treatment with an inhaled corticosteroid on growth and pulmonary function in asthmatic children. Respir Med. 1994:88:373-81.

40. Selroos O, Pietinalho A, Löfroos A-B, Riska H. Effect of early vs. late intervention with inhaled corticosteroids in asthma. Chest. 1995;108:1228-34.

41. Olivieri D, Chetta A, Del Donno M, et al. Effect of short-term treatment with low-dose inhaled fluticasone propionate on airway inflammation and remodeling in mild asthma: a placebo-controlled study. Am J Respir Crit Care Med. 1997;155:1864-71

42. Dales RE, Schweitzer I, Kerr P, et al. Risk factors for recurrent emergency department visits for asthma. Thorax. 1995;50:520-24

43. Hartert TV, Windom HH, Peebles RS Jr, Freidhoff LR, Togias A. Inadequate outpatient medical therapy for patients with asthma admitted to two urban hospitals. Am J Med. 1996;100:386-94.

44. Yamada EG, Roberto L, Sudhakar R, et al. Poor asthma control and inadequate medication regimens in a population of MEDI-CAL children with asthma [abstract]. Am J Respir Crit Care Med. 1999;159:A267.

45. Adams RJ, Fuhlbrigge A, Guilbert T, et al. Inadequate use of asthma medication in the United States: results of the asthma in America national population survey. J Allergy Clin Immunol. 2002;110:58-64.

46. Donahue JG, Fuhlbrigge AL, Finkelstein JA, et al, for The Pediatric Asthma Care Patient Outcomes Research Team. Asthma pharmacotherapy and utilization by children in 3 managed care organizations. J Allergy Clin Immunol. 2000;106:1108-14
47. Diette GB, Skinner EA, Markson LE, et al. Consistency of care with national guidelines for children with asthma in managed care. J Pediatr. 2001:138:59-64

48. Adams RJ, Fuhlbrigge A, Finkelstein JA, et al. Use of inhaled anti-inflammatory medication in children with asthma in managed care settings. Arch Pediatr Adolesc Med. 2001;155:501-07.

49. Weinberger M. Asthma-a problem of health care delivery. Is it time for a new paradigm? Allergy Asthma Proc. 1999;20:57-65.

50. Wennergren G, Kristjánsson S, Strannegård I-L. Decrease in hospitalization for treatment of childhood asthma with increased use of antiinflammatory treatment, despite an increase in the prevalence of asthma. J Allergy Clin Immunol. 1996;97:742-48

51. Adams RJ, Fuhlbrigge A, Finkelstein JA, et al. Impact of inhaled antiinflammatory therapy on hospitalization and emergency department visits for children with asthma. Pediatrics. 2001;107:706-11

52. Donahue JG, Weiss ST, Livingston JM, et al. Inhaled steroids and the risk of hospitalization for asthma. JAMA. 1997;277:887-91

53. Andersson F, Kjellman M, Forsberg G, Möller C, Arheden L. Comparison of the cost-effectiveness of budesonide and sodium cromoglycate in the management of childhood asthma in everyday clinical practice. Ann Allergy Asthma Immunol. 2001;86:537-44

54. Bisgaard H, Price MJ, Maden C, Olsen NA. Cost-effectiveness of fluticasone propionate administered via metered-dose inhaler plus babyhaler spacer in the treatment of asthma in preschool-aged children. Chest. 2001;120:1835-42.

55. Booth PC, Wells NEJ, Morrison AK. A comparison of the cost effectiveness of alternative prophylactic therapies in childhood asthma. Pharmacoeconomics 1996;10:262-68.

56. Connett GJ, Lenny W, McConchie SM. The cost effectiveness of budesonide in severe asthmatics aged one to three years. Br J Med Econ. 1993;6:127-34

57. Rutten-van Mölken MP, Van Doorslaer EK, Jansen MC, Van Essen-Zandvliet EE, Rutten FF. Cost effectiveness of inhaled corticosteroid plus bronchodilator therapy versus bronchodilator monotherapy in children with asthma. Pharmacoeconomics. 1993:4:257-70.

58. Balkrishnan R, Norwood GJ, Anderson A. Outcomes and cost benefits associated with the introduction of inhaled corticosteroid therapy in a Medicaid population of asthmatic patients. Clin Ther. 1998;20:567-80.

59. Smith MJ, Rascati KL, Johnsrud MT. Costs and utilization patterns associated with persistent asthma: a comparison of Texas Medicaid patients with and without continuous inhaled corticosteroid treatment. J Manag Care Pharm. 2001;7:452-59.

60. Sullivan SD, Weiss KB. Health economics of asthma and rhinitis. II. Assessing the value of interventions. J Allergy Clin Immunol. 2001;107:203-10.

61. Liljas, B. and Bisgaard, H. The economic impact of the use of different inhalation devices in childhood asthma. Br J Med Econ. 1997;11:113-19.

62. Coventry JA, Weston MS, Collins PM. Emergency room encounters of pediatric patients with asthma: cost comparisons with other treatment settings. J Ambul Care Manage. 1996;19:9-21.

63. Clark NM, Feldman CH, Evans D, et al. The impact of health education on frequency and cost of health care use by low income children with asthma. J Allergy Clin Immunol. 1986;78:108-15

64. Kelly CS, Morrow AL, Shults J, et al. Outcomes evaluation of a comprehensive intervention program for asthmatic children enrolled in Medicaid Pediatrics. 2000;105:1029-35.

65. Higgins JC, Kiser WR, McClenathan S, Tynan NL. Influence of an interventional program on resource use and cost in pediatric asthma. Am J Manag Care. 1998:4:1465-69.

66. Lahdensuo A, Haahtela T, Herrala J, et al. Randomized comparison of guided self management and traditional treatment of asthma over one year. BMJ. 1996;312:748-52.

67. Mayo PH, Richman J, Harris HW. Results of a program to reduce admissions for adult asthma. Ann Intern Med. 1990;112:864-71. 
68. National Asthma Education and Prevention Program. Role of the pharmacist in improving asthma care. Am J Health Syst Pharm. 1995;52:1411-16.

69. Storms WW. Unmet needs in the treatment of allergic asthma: potential role of novel biologic therapies. J Manag Care Pharm. 2003;9:534-43.

70. Barbanel D, Eldridge S, Griffiths C. Can a self-management programme delivered by a community pharmacist improve asthma control? A randomised trial. Thorax. 2003;58:851-54.

71. Fischer LR, Scott LM, Boonstra DM, et al. Pharmaceutical care for patients with chronic conditions. J Am Pharm Assoc. 2000;40:174-80.

72. McLean W, Gillis J, Waller R. The BC Community Pharmacy Asthma Study: a study of clinical, economic and holistic outcomes influenced by an asthma care protocol provided by specially trained community pharmacists in British Columbia. Can Respir J. 2003;10:195-202.

73. Munroe WP, Kunz K, Dalmady-Israel C, Potter L, Schonfeld WH.

Economic evaluation of pharmacist involvement in disease management in a community pharmacy setting. Clin Ther. 1997;19:113-23.

74. Närhi U, Airaksinen M, Tanskanen P, Erlund H. Therapeutic outcomes monitoring by community pharmacists for improving clinical outcomes in asthma. J Clin Pharm Ther. 2000;25:177-83

75. Herborg H, Soendergaard B, Froekjaer B, et al. Improving drug therapy for patients with asthma-Part 1: patient outcomes. J Am Pharm Assoc. 2001 41:539-50
76. Stergachis A, Gardner JS, Anderson MT, Sullivan SD. Improving pediatric asthma outcomes in the community setting: Does pharmaceutical care make a difference? J Am Pharm Assoc. 2002;42:743-52.

77. Akinbami LJ, Schoendorf KC. Trends in childhood asthma: prevalence, health care utilization, and mortality. Pediatrics. 2002;110:315-22.

78. Evans R III, Gergen PJ, Mitchell H, et al. A randomized clinical trial to reduce asthma morbidity among inner-city children: results of the National Cooperative Inner-City Asthma Study. J Pediatr. 1999;135:332-38

79. Sullivan SD, Weiss KB, Lynn $\mathrm{H}$, et al, for the National Cooperative InnerCity Asthma Study Investigators. The cost-effectiveness of an inner-city asthma intervention for children. J Allergy Clin Immunol. 2002;110:576-81.

80. Jaffe DH, Singer ME, Rimm AA. Air pollution and emergency department visits for asthma among Ohio Medicaid recipients, 1991-1996. Environ Res. 2003;91:21-28

81. Lierl MB, Hornung RW. Relationship of outdoor air quality to pediatric asthma exacerbations. Ann Allergy Asthma Immunol. 2003;90:28-33.

82. Landrigan PJ, Schechter CB, Lipton JM, Fahs MC, Schwartz J. Environmental pollutants and disease in American children: Estimates of morbidity, mortality, and costs for lead poisoning, asthma, cancer, and developmental disabilities. Environ Health Perspect. 2002;110:721-28.

83. Gwynn RC, Thurston GD. The burden of air pollution: impacts among racial minorities. Environ Health Perspect. 2001;109(suppl 4):501-06. 